goes from Novaya Zemlya over to Spitzbergen, availing himself of the archipelagos scattered between the two islands?

IN Nos. 9 and ro of vol. x. of the Transactions of the Berlin Geographical Society, is an address on the wild tribes of Madagascar, by Herr J. Audebert, who divides them collectively, both those of Malayan (the Hovas) and those of African descent, according to their mode of life, into three classes : the inhabitants $(x)$ of the coast ; (2) of the woods; (3) of the grassy lands and steppe-like wastes of the southern interior. Of all the races the Sakalavi are first in point of number, power, and civilisation. The aborigines, or Malagasy proper, are generally of a dark complexion, though those of direct Arabian descent are very clearskinned, with hard features, broad, often also high forehead, eyes wide apart, nose flat, lips prominent, but not swollen, mouth broad, with splendid teeth. The long rather woolly hair is worn in innumerable plaits woven, in the case of the women, into crowns, vaccine ears, snail-shells, \&c., smeared with tallow and ashes into the hardness of stone, and very malodorous. In the grassy interior cattle-rearing is the principal industry: on the coast fishing and the cultivation of rice. In the woods the people live on roots, tubercles, and honey.- Next follows an interesting though brief account of Dr. Stecker's chequered travels, of nearly three years' duration, through Abyssinia. About the middle of February, I88I, when Dr. Rohlfs left Debra Tabor, Dr. Stecker made his way to the Tana Lake, which he travelled round, sending a detailed map of it, executed on the spot, to the German African Society. At Zabul, the recently-acquired seat of King John, Dr. Stecker drew a plan of the grand and interesting chain of mountains traversing the eastern part of Abyssinia, but both report and map failed to reach the German African Society, whither they were directed. Dr. Stecker was bent on penetrating into Koffa, but on account of war tumults and King John's refusal to give him permission, was obliged to abandon his design. IIe, however, joined the three kings, King John, the King of Shoa, and the Negus Tekla Haimanot into the Eastern Gala lands of Komboltsha, Antsharo, Tshaffa, Rikke, and Argobba, and was thus enabled to make first acquaintance with a tract of country never. before trodden by a European. - Some interesting particulars of travel in South America are taken from a letter of Dr. G. Steinman to Dr. W. Reiss, dated November 5, I883.-The stones collected by Herr P. Guissfeldt on the north-west slopes of Aconcagua, at a height of from 5500 to 6roo metres have been analysed by Prof. J. Roth of the Academy of Sciences, and the result has established beyond all further doubt the fact that Aconcagua is a volcano.

\section{THE ORIGIN OF THE SCENERY OF THE}

\section{BRITISH ISLANDS}

A TRUE mountain chain is the result of a local plication of the earth's crust, and its external form, in spite of sometimes enormous denudation, bears a close relation to the contours produced by the original uplift. Tried by this standard, hardly any of the heights of Britain deserve the name of mountains. With some notable exceptions in the south of Ireland, they are due not to local but to general upheavals, and their outlines have little or no connection with those due to underground movement, but have been carved out of upheaved areas of unknown form by the various forces of erosion. In the course of their denudation the nature of these component rocks has materially influenced the elaboration of their contours, each wellmarked type of rock having its own characteristic variety of mountain forms. The relative antiquity of our mountains must be decided not necessarily by the geological age of their com. ponent materials, but by the date of their upheaval or of their exposure by denudation. In many cases they can be shown to be the result of more than one uplift. The Malvern Hills, for example, which from their dignity of outline better cleserve the name of mountains than many higher eminences, bear internal evidence of having been upheaved during at least four widely se arated geological periods, the eailiest movement dating from before the time of the Upper Cambrian, the latest coming down to some epoch later probably than the Jurassic period. The oldest mountain fragments in Britain are those of the Archæan rocks, and of these the largest portions occur in the north-west

Abstract of second lecture given at the Royal Institution, February 5, by Archibald Geikie, F.R.S., Director-General of the Geological Survey. Continued from p. 325 . of Scotland. Most of our mountains, however, belong to upheavals dating from Palæozoic time, though the actual exposure and shaping of them into their present forms must be referred to a far later period. Two leading epochs of movement in Palæozoic time can be recognized. Of these the older, dating from before the Lower Old Red Sandstone and part at least of the Upper Silurian period, was distinguished by the plication of the rocks in a dominant north-east and south-west direction, and the effects of the:e movements can be traced in the trend of the Lower Silurian ridges and hollows to the present day. In Wales two types of mountain-form exist-the Snowdon type, and that of the Breconshire Beacons. In the former the greater prominence of the high grounds arises primarily from the existence of masses of volcanic rocks, which from their superior durability have been better able to withstand the progress of degradation. In the latter the heights are merely the remaining fragments of a once continuous tableland. The Lake District presents a remarkable radiation of valleys from a central mass of high ground. It might be supposed that these valleys have been determined by some radiating system of fractures in the rocks; but an examination of the area shows them to be singularly independent of geological structure. So entirely do they disregard the strike, alternations, and dislocations of the rocks among which they lie that the conclusion is forced upon us that they have been determined by some cause wholly independent of structure, and before the present visible structure was exposed at or could affect the surface. This could only have happened by the spread of a deep cover of later rocks over the site of the Lake mountains. The former presence of such a cover, which is demanded for the explanation of the valleys, can be inferred from other evidence. The Carboniferous Limestone on the flanks of the Lake District is so thick that it must have spread nearly or entirely over the site of the mountains. But it was overlaid by the Millstone Grit and Coal-measures so that the whole area was probably buried under several thousand feet of Carboniferous strata which stretched continuously across what is now the north of England. At the time of the formation of the anticlinal fold of the Pennine Chain the site of the Lake District appears to have been upraised as a dome-shaped eminence, the summit of which lay over the tract now occupied by the heights from Scafell to Helvellyn. The earliest rain that fell upon this eminence would gather into divergent streams from the central watershed. In the course of ages, after possibly repeated uplifts, these streams have cut down into the underlying core of old Palæozoic rocks, retaining on the whole their original trend. Meanwhile the whole of the overlying mantle of later formations has been stripped from the dome, and is now found only along the borders of the moun. tains. The older rocks yielding to erosion, each in its own way, have gradually assumed that picturesqueness of detail for which the area is so deservedly famous. The Scottish Highlands likewise received their initial plications during older Palæozoic times their component rocks having been thrown into sharp fold, trending in a general north-east and south-west direction. But there is reason to believe that they were in large measure buried under Old Red Sandstone, and possibly under later accumula. tions. No positive evidence exists as to the condition of this region during the vast interval between the Old Red Sandstone and the older Secondary rocks. We can hardly believe it to have remained as land during all that time, otherwise, the denudation, vast as it is, would probably have been still greater. Not improbably the region had become stationary at a base-level of erosion beneath the sea; that is, it lay too low ro be effectively abraded by breaker-action, and too high to become the site of any important geological formation. The present ridges and valleys of the Highlands are entirely the work of erosion. When they began to be traced the area must have presented the aspect of a wide undulating tableland. Since that early time the valleys have sunk deeper and deeper into the framework of the land, the ridges have grown narrower, and the mountains have arisen, not by upheaval from below, but by the carving away of the rest of the block of which they formed a part. In this evolution, geological structure has played an important part in guiding the erosive tools. The composition of the rock-masses has likewise been effective in determining the individuality of mountain-forms. The mountains of Ireland are distributed in scattered groups round the great central plain, and belong to at least three geological periods. The oldest groups probably took their rise at the time of the older Palæozo:c upheaval, those of the northwest being a continuation of the Scottish Highlands, and those 
$\mathrm{f}$ the south-east being a prolongation of those of Wales. Later in date as regards the underground movements that determined their site, are the mountainous ridges of Kerry and Cork. These are local uplifts which, though on a small scale, are by far the best examples in Britain of true mountain structure. The old Red Sandstone and Carboniferous rocks have there been thrown into broad f,lds and troughs which run in a general east and we-t direction. In some cases, as in the Knockmealdown Mountain, the arch is composed entirely of Old Red Sandstone flanked with Carboniferous strata. But in most instances an underlying wedge of Lower Silurian rocks has been driven through the arch. As not only the Carboniferous Limestone, but the rest of the Carboniferous system covered the south of Ireland and participated in this plication, the amount of denudation from these ridges has been enormous. On the Galty range, for example, it can hardly have been le:s but may have been more than 12,000 feet. The third and late:t group of Irish mountains is that of Mourne and Carlingf.rrd, which may with some probability be referred to older Tertiary time when the similar granitic and porphyritic masses in Mull and Skye were erupted.

The tablelands of Britain strictly include the mountains, which are in general only prominences carved out of tablelands. But there are still large areas in which the plateau character is well shown. Of these the most extensive and in many respect the most interesting is the pesent tableland or plain of Central Ireland. As now exposed, this region lies upon an undulating eroded surface of Carboniferous Limestone. But it was formerly covered by at least 3000 or 4000 feet more of Carboniferous strata, as can be shown by the fragnents that remain. The present system of drainage across the centre of Ireland took it; ori jin ling befure the ancient tableland had been reduced to its present level, and before some of the ridges, now prominent, had been exposed to the light. The Moors and Wolds of Yorkshire present us with a fragment of a tableland conposed of nearly horizontal Jurassic and Cretaceous rocks. The Lammermuir Hills and Southern Uplands of Scotland form a broad tableland which has been formed on a deeply eroded surface of Lower Silurian rocks.

\section{THE MONK FISH}

NATUREN has recently supplied its readers with some interesting details concerning the so-called "monk-fish" of the Sound, which may be regarded as the genuine forerunner of the sea-serpent of modern times. Its capture and appearance were deemed worthy of record in Arild Hirtfeld's great "History of Denmark," published in I595, while portraits of the sea-monk embellished the works of various Scandinavian and German natural history writers of the middle of the sixteenth century. Among these, Guillaume Rondelet, in his great folio work, "Libri de Piscibus Marinis," first claimed the special privilege of giving to the world a facsimile of the authentic likeness of the monk. This, we are assured, bad been taken from life for, and in the presence of, a nobleman, who had caused one copy to be made for the Emperor Charles V., and another for Margaret, Queen of Navarre, by whom it was presented to the author. Hirtfeld does not profe:s to have been brought into such close connection with the original, but he and the historians, Krag and Stephanius, agree in reporting that fish, bearing the semblance of a human head with a monk's shaven crown, and having torn or mutilated limbs indistinctly defined under a scaly covering, was, in the year 1550 , captured in the Sound, in a herring.fisher's net, and brought to the King of Denmark, who immediately gave orders that it should be buried de sp underground, " to hinder indiscreet talk among the ignorant, whose minds are always perturbed by what is new." The speedy burial of the monster did not allay the excitement caused by its apparition, and Rondelet found, to his extreme annoyance, that his Swiss friend, Gesner, and other philosophers then in Rome, were in possession of other reputed original likenesses of the monk, differing from his own. This circumstance, he admits, inclined him to suspect that the artist had added "this or that according to fancy to make the fish seem more wonderful than it was in reality." He even confesses that some of the portraits have no more resemblance to a human head than might be detected in a frog or a toad; that the extremities look like fins, and that the so-called monk's gown is more like a dark seal's skin than a scaly armour. From these and other corrections, coupled with Gesner's mention of a fish's tail having formed part of the monk's body, Prof. Steenstrup infers that the "monk-fish" was an unusually large specimen of the Loligo or Squid family, whose caudal extremity, bearing probably bruises or other marks on the skin, had acquired in the imagination of the spectators the semblance of a head and neck with torn-off arms, while the arms of the cephalopod had served to represent lacerated extrenities. A comparion of the numerous conflicting contemforaneous descriptions of the Danish "sea-monk" and of the later " Kraken" of the old Norwegian Bishop Pontoppidan might possibly be not wholly useless in the present day in checking an over hasty confidence in the truth of every fresh tale of encounters with sea-serpents, as recorded by credulous seafaring men. We may, in the meanwhile, refer all who are interested in sea-monsters to the July number of Naturen, in which they will find a faithful representation of Rondelet's monk-fish, while the September number of the same journal gives reproductions of two characteristic Japanese pictures, in one of which a solitary boatman is battling in a stormy sea with a formidable creature, evidently a highly magnified form of octopus, one of whose arms has been severed as it encircled man and boat, while the other arms are represented as striving to draw their prey nearer to the huge head with its protruding eyes. In the second picture, which, if less forcible, is more realistic, we see in the wondering and terrified expression of the assembled men and boys the surprise and alarm excited by the appearance at a fishmonger's stall of two octopus arms, not unlike suspended serpents. The terror of the spectacle has communicated itself to domestic animals-a dog hiding himself, while a cat is taking rapid flight up the roof of the house.

\section{UNIVERSITY AND EDUCATIONAL} INTELLIGENCE

OxFord. - The Examiners for the Radeliffe Travelling Fellowship give notice that the examination will commence on February 20 at $\mathrm{roa}_{\mathrm{m}} \mathrm{m}$. in the University Museum. The Examination for the Burdett-Coutts Geological Scholarship will commence on March 3 at ro a.m.

Mr. Robert Stockdale, of Giggleswick School, has been elected to a Hastings Exhibition in Natural Science at Queen's College.

CAMBRIDGE:-The following are the words spoken by the Public Orator in presenting Dr. Hans Gadow (formerly of the British Museum), Curator of the Strickland Collection of Birds, for the complete degree of M.A. honoris causâ :-

"Dignissime Domine, Dumine Procancellarie et tota Academia : Anni proximi sub finem (iuvat recordari) fabulam illam Aristophanis qua Aves nominatur cum voluptate maxima prope omnes spectavimus. Hodie vero, ad studia nostra severiora redeuntes, nihil auspicatius esse arbitramur, quam annum novum honore in illum collato signare qui omnium avium genera et naturas quasi propriam provinciam sibi sumpsit explorandam. Illum igitur senatoribus nostris hodie merito adscribimus, qui Pomeraniæ maritimæ in parte orientali a gente antiquissima oriundus in celeberrimis Germaniæ Academiis zoologiæ, palæon tologix, mineralogiæ, studiis operam suam feliciter impendit; qui quarto abhinc anno in Britanniam idcirco est vocatus, ut aves in Museo Britannico conservatas summa cura describeret qui in nostra denique Academia nuper non modo de vertebratis quæ dicuntur animalibus prælectiones habutit doctissimas, sed etiam thesauris nostris ornithologicis custcdiendis cum fructu nostro maximo est præpositus. Inter antiquos quidem avinm a volatu cantuque rerum futurarum omina ducebantur; nos meliora edocti hodie in hoc viro Procancellarii novi auspicii. veram avium scientiam laude debita exornamus, ex initio tam felici omnia fausta in futurum augurati. 'Date candida cives Omina, et inceptis dexter cantet avis.' Vobis præsento virum et de studiis ornithologicis et de Academia nostra optime meritum, Hans Gadow.

Mr. W. F. R. Weldon, B.A., St. John's College, has been appointed Demonstrator of Comparative Anatomy.

Mr. Francis Galton, F.R.S., has been appointed Rede Lecturer for the present year.

Prof. W. J. Sollas, M.A, late Fellow of St. John's College, First Class in the Natural Sciences Tripos, 1873, and Mr. P. H. Carpenter, M.A., Trinity College, First Class in the same Tripos, 1874 , have been approved for the degree of Doctor of Science. The able original works in Geology and Zoology by both these gentlemen are familiar to all students. 